\title{
Okos valóság Magyarországon? Okos programok megvalósításának esélyei Miskolcon és a magyar-szlovák határ menti térségben
}

\section{Smart reality in Hungary? The chances of implementation of smart programmes in Miskolc and the Hungarian- Slovak cross-border region}

\author{
JÓZSA VIKTÓRIA, KNEISZ ILDIKó
}

JózSA Viktória: ügyvezető, Nord Consult Kft.; 1106 Budapest, Jászberényi út 45., 2. emelet; viktoria.jozsa@gmail.com; https://orcid.org/0000-0002-6897-080X

KNEISZ Ildikó: egyetemi tanársegéd, Miskolci Egyetem, Világ- és Regionális Gazdaságtan Intézet; 3515 Miskolc, Egyetemváros; kneisz.ildiko@gmail.com; https://orcid.org/00000003-2855-880X

KULCSSZAVAK: okos város; okos közösségek; területi egyenlőtlenségek; pilot projektek

ABSZTRAKT: A hazai városok „smart city”-vé alakulásának támogatása a kormányzat kiemelt célja, és ezzel összehangban több hazai város is zászlajára tűzte az okosvárosprogramot. A cél elérése érdekében az elmúlt években számos település kapcsolódott nemzetközi együttműködésekhez, egyrészt a programhoz szükséges hazai forrás hiánya miatt, másrészt a nemzetközi jó gyakorlatok megismerése és alkalmazása céljából. Elsősorban a megyei jogú városok és a fóvárosi kerületek indítottak ilyen tevékenységeket, de vajon csak a nagyvárosok kiváltsága a „smart”-ság? Kutatásunk egyik célja annak a hipotézisnek az alátámasztása, hogy az „okosság” a vidéki, elmaradott kistelepülések esetében is értelmezhető. Igaz, más megközelítés és módszertan alkalmazásával. Fentiek illusztrálására két nemzetközi kutatási projekt eddigi tapasztalatait vizsgáljuk: az országban egyedülálló Horizont 2020-as projektet, amely egy hazai nagyváros részvételével zajlik; valamint egy alapvetően más koncepcióval megvalósuló projektet, amely a határ menti, hátrányos helyzetű kistelepülések összefogására épül. Az esettanulmányok segítségével igyekszünk választ kapni arra, hogy a smart programok megvalósulásának - különböző típusú települések esetében - milyen realitása van hazánkban. A téma aktualitása a következő (2021-2027) európai uniós programozási időszak tervezésekor kiemelkedő lesz, mivel a megfogalmazott tanulságok, tapasztalatok a szakpolitika számára fontos kiindulási alapot jelenthetnek.

Viktória JÓZSA: CEO, Nord Consult Kft.; Jászberényi út 45., 2. emelet, H-1106 Budapest, Hungary; viktoria.jozsa@gmail.com; https://orcid.org/0000-0002-6897-080X

Ildikó KNEISZ: assistant lecturer, Institute of World and Regional Economics, University of Miskolc; Egyetemváros, H-3515 Miskolc, Hungary; kneisz.ildiko@gmail.com; https://orcid.org/00000003-2855-880X

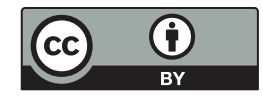


KEYWORDS: smart city; smart communities; territorial inequalities; pilot projects

ABSTRACT: The transformation of Hungarian cities into 'smart cities' is one of the government's priorities. Therefore, several cities have started to implement smart initiatives. International cooperation is an efficient solution in this area for two reasons: firstly, because specific national funds or subsidy programmes are lacking, and secondly because such cooperation offers excellent opportunities to test and adapt relevant and up-to-date international good practices. Especially cities with county rank and districts in the capital have initiated smart projects. But is it actually the privilege of cities to be smart? Our research goal was to verify the basic hypothesis that smartness can also be transferred to less developed rural small towns if suitable approaches and methodology are applied. To this end, we conducted a qualitative empirical analysis based on two case studies from the less developed North Hungarian region (convergence region).

After a short introduction to the Hungarian situation in an international context and to the state of the art, we present the results of a secondary analysis and case study research, especially regarding the applied project concepts and methods as well as non-technical solutions. What we have investigated are the medium-term results of two international projects: a unique Horizon2020 Smart Cities and Communities flagship project involving a Hungarian medium-sized city (Miskolc) as a so-called Follower City and a cross-border (Interreg Slovakia-Hungary) project based on inter-institutional cooperation in a less-advantaged peripheral micro-region. So in the same NUTS2 region (Northern Hungary), the clearly different conceptual context and the prospects for the implementation of smart programmes in the case of a medium-sized city (big city by Hungarian standards) and small neighbouring villages were examined. Although the two projects analysed differ in approach, scope, settlement type and methodology, they are carried out in the same Hungarian region, in the same period and in the same sectoral area of Smart Cities and Communities. The medium-term results allow some conclusions to be drawn about the main challenges, positive and negative experiences and critical points in the implementation of smart programmes in contemporary Hungary.

With regard to the strategic priorities at national level and the first initiatives at local level, a decline and a lack of orientation can currently be observed. After initially promising activities to transfer good practice and to benchmark, national coordination, strategic planning and policy initiatives remained insufficient, as did the allocation of necessary funding. The main bottlenecks are the lack of competence and capacity of local governments, the low level of citizen participation and commitment, the insufficient involvement of 'grassroots' initiatives and the issues of ethical and transparent use of private data. Even more important is the need to change attitudes towards a holistic and ecosystem-based approach that seeks a balance between economic growth and social cohesion.

Given the current planning phase for the next EU programme period of 2021-2027, including the Horizon Europe programme, the issue is extremely topical and significant. The pilot projects can serve as a proof of concept, and the interim results and conclusions presented can provide a solid basis for future policy interventions and measures in the field of smart cities and municipalities. What is required now is action.

\section{Bevezetés}

A kormányzat elkötelezettségét a smart city témája iránt leginkább a 2014-ben kiadott, a Digitális nemzet fejlesztési program elkészítéséről, és a smart cityfeladatok szakmai koordinációjáról szóló, egy évvel későbbi kormányhatározat támasztja alá. Az 56/2017. (III. 20.) kormányrendelet hivatalosan is meghatározza az okos város fogalmát: „Az okos város olyan település vagy településcso- 
port, amely természeti és épített környezetét, digitális infrastruktúráját, valamint a területén elérhető szolgáltatások minőségét és gazdasági hatékonyságát korszerű és innovatív információtechnológiák alkalmazásával, fenntartható módon, lakosainak fokozott bevonásával fejleszti."

Mit is jelent mindez a gyakorlatban? A Lechner Tudásközpont által összeállított és online elérhető, nemzetközileg is egyedülálló példatár (http:// okosvaros.lechnerkozpont.hu/hu) számos kortárs esetet mutat be, amelyek között technológiaalapú és nem technológiaalapú megoldások egyaránt megtalálhatók. A Tudásközpont által kifejlesztett településértékelési és monitoringrendszer - a nemzetközi gyakorlatot (az EU Smart City Ranking és a Smart Cities Council indexét) követve - hat alrendszer (kormányzás, gazdaság, környezet, mobilitás, életkörülmények, emberek) mentén vizsgálja a városokat (Lechner Központ 2018).

A komplex és integrált megközelítés azért fontos, mert az okosváros-koncepció megjelenése óta eltelt több mint egy évtizedben a megoldások meghatározó része technológiai jellegü volt, figyelmen kívül hagyva például az emberi tényezőket, és a kritikai elemzések is csak az elmúlt években jelentek meg. A városi laborok ${ }^{1}$ külön kategóriát alkotnak, és míg a legtöbb sikeres kezdeményezés ezek keretében jött létre, a nemzetközi tapasztalatok azt mutatják, hogy minden 7-10 projektből 1 valósul meg, a többi a fejlesztés valamely szakaszában megszünik (Vermast 2018).

Hazánkban a példatár szerint az elmúlt években csaknem 100 okos kezdeményezés valósult meg. Egyes városok kiemelkedő aktivitással valósítják meg az okos kezdeményezéseket: Budapest abszolút vezető pozícióban szerepel 44 projekttel, Debrecen 14, Szolnok 12 okos kezdeményezéssel rendelkezik.

Debrecen esetében a kezdeményezések között megtalálhatók bigdata-alapú projektek (például a Debrecen - WAZE együttmüködés és az Open Data Debrecen), mobilitást támogató projektek (például az e-mobilitás az E.ON-nal és az UniBike), és kiemelendők a városi gazdasági miliőt és közösségépítést erősítő kezdeményezések (Debrecen Smart City Meetup, NI Mentor Program, Startup Kerekasztal). Fontos megjegyezni, hogy a kezdeményezések megvalósításában a Debreceni Önkormányzat szorosan együttműködik a nagyvállalatokkal (közmüszolgáltatókkal és technológiai vállalatokkal). Szolnok egységes ernyőmárka (T-City) alá rendezi kezdeményezéseit, amelyben megtalálható az e-mobilitást (E.ON, MobilVáros), az energia- és erőforrásgazdálkodást (intelligens közvilágításvezérlő rendszer és optimális energiamenedzsment-rendszer, vízminőségmérő állomás) és a városi lakosság digitális írástudásának és a világháló illemtanának (netikett) elsajátítását támogató projekt (internetakadémia, T-City Kids szakkör) is. Miskolc esetében - a tanulmányunkban részletesen bemutatott nemzetközi kezdeményezés miatt is fontos említenünk - a példatár négy projektet nevesít: e-mobilitás (ELMÜ-ÉMÁSZ); integrált utastájékoztatási és forgalomirányítási rendszer; Logischool szakkör; és MVK Free WiFi. Látható, hogy Miskolcon a kezdeményezések többsége a közösségi közlekedésre és mobilitásra koncentrál. 
A példatárban szereplő projektek mellett az okos kezdeményezések köre hazánkban évről évre bővül, bár inkább az egyes települések szintjén, önkéntes alapon. Kaposvár, Miskolc és Szolnok a Nyitott és agilis okos városok nemzetközi kezdeményezés tagjai, Miskolc az Urban Agenda for the EU kezdeményezésben együttműködő partner. A kezdeti lelkesedést és az első kezdeményezések sikeres megvalósítását követően (amit az angol nyelvű fejlesztéspolitikai szakirodalom könnyen elérhető gyümölcsökként - low hanging fruits - nevesít) a továbblépésnek, az intézményesülésnek és a rendszerszintű elterjedésnek számos akadálya van. Az okosváros-kezdeményezések sajátossága - amely előnyként és hátrányként egyaránt említhető -, hogy a köz- és magánszféra együttmüködése (publicprivate partnership, PPP) keretében jönnek létre, és működésük során is megőrzik ezt. Ez lehetőséget ad az együttműködés „,kulisszatitkainak” megtanulására, majd további területekre történő kiterjesztésére. Az okosváros-kezdeményezéseket sok kritika is éri. Ezek közül a leggyakoribbak a túlzott technológiai és infrastrukturális fókusz; az egyéni/szervezeti érdekek meghatározó jellege a közösségben, az ökoszisztémában való gondolkodással szemben; valamint a „big data” és azon belül a városi adatok gyüjtésének, kezelésének és elemzésének kérdésköre kiemelten a helyi lakosság és az etikus és áttekinthető felhasználás kapcsán. A következőkben ezekre részletesebben is visszatérünk.

A tanulmányban röviden áttekintjük a téma nemzetközi hátterét, majd a két nemzetközi projektet és azok eddigi tapasztalatait mutatjuk be, végül összegezzük a smart programok hazai realitásáról alkotott véleményünket.

\section{Nemzetközi kitekintés, elméleti háttér}

A napjainkat meghatározó globális tendenciák minden közösség számára új kihívásokat hoztak, függetlenül az adott közösség méretéről, földrajzi elhelyezkedésétől vagy a településhierarchián belül elfoglalt pozíciójától. Különösen igaz ez a vidéki városok és a kistelepülések esetében a helyi társadalom és gazdaság, illetve az egyének szintjén. Mind a nemzetközi, mind a hazai szakirodalomban az „okossággal” kapcsolatos kutatások középpontjában eddig a nagyvárosok álltak. Az okosságot elsősorban mérethez, lakosságszámhoz, városi funkciókhoz és fizikai infrastruktúra meglétéhez kötötték. Az „okossá válás” fo célja ennek megfelelően hatékonysági és technológiai fókuszú volt.

Az okos, fenntartható és élhető városok mint kulcsszavak a kortárs városfejlesztési nyelvezet divatos kifejezései, amelyek megteremtik a kereteit a városi működés megértésének, konceptualizálásának és tervezésének (Söderström, Paasche, Klauser 2014). Az okos városokkal kapcsolatos szakirodalom két fó csoportra osztható, amelyek közül az első a városok számára fejleszthető és elérhető technológiai megoldásokra helyezi a hangsúlyt (Bakici, Almirall, Wareham 2013; Paskaleva 2011, Rat-Fischer et al. 2012), míg a második az okos várost a technoló- 
giák összeházasításának, fúziójának termékeként értelmezi (Allwinkle, Cruickshank 2011; Caragliu, Del Bo, Nijkamp 2011). A városiasodással és városi léttel járó kihívások és kérdések bináris nyelvre és mérnöki problémákra való lefordítása nagyon elterjedt. Ezek a problémák pedig - például az IBM által javasoltan - az angol nyelvü meghatározás alapján "három I”-ként nevezett megoldással (instrumentation, interconnection and intelligence, azaz eszközalapúság, összekapcsoltság és intelligencia) kezelhetők, és a szükséges szakértelem ezáltal az adatbányászat és a programozás területeire korlátozódik.

Az elmúlt években egyre több kritikai elemzés jelent meg az okos városokkal kapcsolatban. Az egyik legelső ilyen elemzés Hollands (2008) tanulmánya, aki rámutatott az új technológiák városokban történő alkalmazásainak néhány negatív hatására, közöttük például az erősödő társadalmi polarizációra és a társadalmi egyenlőtlenségek növekedésére. Söderström és társai (2014) a „smart city" kifejezés közösségi szférán belül való felbukkanásának és gyors terjedésének folyamatát vizsgálta, és ennek kapcsán részletesen elemezte az IBM globális hatását a smart city-koncepció és alkalmazások területén. Az IBM - többek között hagyományos üzleti területeinek gyengülése miatt - globális történetként, a piaci rést felismerve próbálta meg magát kötelező áthaladási pontként meghatározni (Callon 1986) a városok „okosításának” folyamatában. Taktikája a szerzők szerint az volt, hogy az adott város kiindulási helyzetét problematizálva magát egyedüli megoldásnyújtóként tüntette fel.

A kritikai szakirodalom sem fordított azonban megfelelő mértékü figyelmet két fontos kérdésre. Az első, hogy az okosság nem városi kiváltság, a vidéki (rurális) kistelepülések is okossá válhatnak lakosságszemléletű (citizen-based) fejlesztésekkel, amelyek a fizikai infrastruktúra helyett (mellett) a helyi közösségekre, az emberi tényezőre helyezik a hangsúlyt. Naldi, Nilsson és Westlund (2015) okos vidékfejlesztésről írt tanulmánya az okos növekedést (smart growth) a fenntartható fejlődéshez kapcsolja, és hangsúlyozza az okos fejlesztések alkalmazhatóságát a vidéki területeken. Ugyanez az elemzés az okos vidékfejlesztési beavatkozások hatásainak mérési lehetőségeivel is foglalkozik. A második fontos kérdés az új, hálózatosodott gazdaságban, hogy bár a városok a gazdasági hálózatok gócpontjai, azokat nem lehet vonzáskörzetük nélkül vizsgálni és fejleszteni. Ha az „okosság körét” a közigazgatási határral lezárjuk (a határ elválasztó funkcióját alkalmazva), a rendszerszintü működést negatív irányba befolyásoljuk, és az egyenlőtlenségek a város és vidéke (környéke, esetenként agglomerációja) között tovább növekednek a bővülő munkamegosztás és az együttmúködés helyett.

Mint ahogy Vanolo (2014) is kiemeli, az „,adatot a lakosságnak” megközelítése helyett a technológiailag és digitálisan művelt, vagy legalábbis írástudó okos lakosok számának növelésére kell a hangsúlyt áthelyezni. A szerző arra is rámutat, hogy az okos városokkal kapcsolatos viták nem foglalkoznak azzal a kérdéssel, hogy a technológiai szempontból „írástudatlan”, többnyire szegény és marginalizált társadalmi csoportok hogyan tudnának bekapcsolódni az okos 
folyamatokba. A vidéki térségek okosítása kapcsán ez a probléma fokozottan érvényes. Nyitott és okos hozzáállás (smart mentality) szükséges a számítástechnikai algoritmusok helyett, vagy azokat kiegészítve. Visszanyúlva az okosváros-koncepció gyökereihez - amely újfajta kapcsolatok létrehozását célozta a technológia és a társadalom között - nyilvánvaló, hogy erre a vidéki társadalmak esetében is van lehetőség. Mi az oka akkor annak, hogy a világméretü „okosítási” folyamatban a vidéki kistelepülésekre csak nagyon kevés figyelem jut? Egy lehetséges ok a méretgazdaságosság lehet, azaz a gazdasági-pénzügyi érdekeltség hiánya a megtérülési számítások alapján (Boltanski, Thévenot 2006). Másik okként feltételezhető, hogy a fizikai infrastruktúrák müködését sokkalta könnyebb bináris nyelvre lefordítani, mint a lakosság tevékenységeit és elvárásait. Pedig a fenntartható és biogazdálkodás, az öko- és okos otthonok, az optimalizálás és automatizálás alkalmanként még egyszerübb is a kistelepülések esetében, mint a nagy, túlterhelt és bonyolult nagyvárosi közösségi rendszerekben.

A szakpolitikai kapcsolódásokat vizsgálva megállapíthatjuk, hogy bár az Európai Unió szakpolitikájában a téma hangsúlyosan csak 2016-ban jelent meg az EU Action for Smart Villages intézkedéscsomag keretében, ám az ENRD (European Network for Rural Development) tematikus munkájában már régebb óta szerepeltek komplex fejlesztési prioritások és technológiai elemek. Több európai országban is 5-10 éve zajlanak okosfalu- és okosrégió-programok (Észak-Olaszországban a Milánó-Torino közötti régióban - Morandi, Rolando, Di Vita 2016 -, Németországban a Fraunhofer Digitale Dörfer programjában). Fel kell hívni a figyelmet, hogy az okos falvak és régiók kapcsán a legtöbb kutatás és mintaprojekt Indiában (például India Smart Villages) és Afrikában (például E4SV Smart Villages, IEEE Smart Village program) található. A kelet-közép-európai régióban eddig relatíve kevés figyelem irányult a témára, ezért is foglalkozunk ezzel a kérdéssel.

Arra a kérdésre keressük a választ két konkrét nemzetközi projekt félidős megvalósítási tapasztalatai alapján, hogy van-e az okos városoknak és az okos vidéki kisközösségeknek realitása napjainkban Magyarországon. Módszertanilag eltérő nagyságú és típusú településeket választottunk az Észak-Magyarország régióban esettanulmányként, amelyek nemzetközi projektek keretében, széles körű partnerségben valósítanak meg „okos” kezdeményezéseket. Az egyik nemzetközi projekt - és az azt támogató program - kutatás-fejlesztési, technológiai és innovációs fókuszú (Horizont 2020), míg a másik a határon átnyúló, intézmények közötti, területfejlesztési aspektusokra helyezi a hangsúlyt (Interreg Szlovákia-Magyarország). Ennek megfelelően a projektek belső felépítése, a megvalósítás módszertana és a konkrét projekttevékenységek is eltérők. Megközelítésünk szerint a vidéki nagyvárosokban is integrált, komplex megközelítés szükséges az okossá válási folyamat során. A vidéki kistelepülések esetében pedig szintén lehetséges az okos településsé válás, esetükben a „puha”, endogén fejlesztési tényezőkre kell a fejlesztéseket alapozni, és okos közösségek kialakulását kell támogatni az okos infrastruktúrák és technológiai rendszerek helyett (és mellett). 


\section{A kutatás eredményei}

\section{Miskolc Zöld Város és a REMOURBAN projekt}

Miskolc nemzetközi viszonylatban közepes méretű város, hazai viszonylatban nagyváros. A város nehézipari múlttal rendelkezik és az elmúlt években mint zöld város definiálta újra magát. Ennek a koncepciónak a részeként csatlakozott 2014-ben a REMOURBAN (REgeneration MOdel for smart URBAN transformation, az okos városi átalakulás új modellje) rövidítésű nemzetközi projekthez, amelyet egy 22 fös nemzetközi konzorcium valósít meg az Európai Unió Horizont 2020 Smart Cities and Communities programjának támogatásával. Miskolc a hazai városok közül elsőként tudott részt venni e magas presztízsű és az Európai Bizottság kiemelt figyelmét élvező programban. A projekt 2015. január 1-jén indult, a projekt megvalósításának időtartama öt év. A zászlóshajóprojekt teljes költségvetése mintegy 23,8 millió euró, amelyből az EU-társfinanszírozás összege mintegy 21,5 millió euró (nagyjából 90\% a támogatási intenzitás) (http://www.remourban.eu 2018).

A projektkonzorciumban hét ország szervezetei vesznek részt, három világítótorony- (lighthouse) és két követő (follower) városban valósulnak meg a projekttevékenységek. A fó cél a részt vevő városok fenntarthatóvá alakítása egy holisztikus és könnyen másolható városi regenerációs modell megalkotásával, amelyet a világítótoronyvárosokon (Nottingham, Egyesült Királyság; Valladolid, Spanyolország; és Tepebaşı/Eskişehir, Törökország) tesztelnek és értékelnek, miközben a modell további alkalmazási potenciálját a maximumra fejlesztik két követő város (Seraing, Belgium; Miskolc) példáján.

A konzorcium felépítése kiegyensúlyozott, abban 5 város, 3 kutatóintézet, 5 ipari nagyvállalat és 9 kis- és közepes vállalkozás szerepel, a kutatók mellett kivitelező vállalatok, közüzemi szolgáltatók, önkormányzatok és intézményeik, ipari partnerek, kisvállalkozások, az eredmények hasznosulását és kommunikációját támogató szakértő cégek és befektetők. A projekt célcsoportjába egyaránt tartoznak döntéshozók, befektetők, a közösségi szektor, ipari partnerek, ezáltal a technológiai és az azokat támogató pénzügyi megoldások közötti kapcsolat és innovatív együttmüködés jelentősen javítható, ami a hosszú távú fenntarthatóság kulcsa.

Módszertanilag a modell az energetika, mobilitás és IKT (információskommunikációs technológia) konvergenciájának kihasználására törekszik a lakosság életszínvonalának, tudatosságának, városi kormányzásban való részvételének és a megoldások társadalmi befogadásának növelése érdekében. A projekt során a partnerek számos technikai-technológiai innovációt, szervezeti és gazdasági megoldást, a városmegújítás új üzleti modelljeit is alkalmazzák, azok alapján esettanulmányokat elemeznek, valamint a nem technikai jellegű akadályok leküzdésére konkrét stratégiát is kidolgoznak. 
A fö indikátorok is fenti célnak alárendelve születtek és meglehetősen ambiciózusak:

- az emberi tevékenység által okozott káros hatások csökkentése 5\%-kal a részt vevő városokban, mind az egy före jutó éves széndioxid-kibocsátásban, mind pedig az egy före jutó éves energiafelhasználásban;

- az épületek energiaszükségletének 40\%-kal történő csökkentése és az osztott energiaelőállítás arányának 30\%-ra való emelése;

- a hő- és elektromosenergia-elosztás hatékonyságának 10\%-kal való emelése olyan PPP-beruházásokban, amelyek megtérülési ideje rövidebb 15 évnél az épületek/kerületek, és rövidebb 5 évnél az energiaellátáshoz kapcsolódó beavatkozások esetében;

- az alacsony szén-dioxid-kibocsátással járó mobilitási megoldások 5\%-kal (középtávon 25\%-kal) történő emelése, ami a szén-dioxid-kibocsátás 50\%-os csökkentését és a háztól házig tartó utazási idő 10\%-os csökkenését jelenti;

- a lakosság tudatosságának növelése által az egy före jutó energiafelhasználás 10\%-os csökkentése.

A demonstrációs tevékenységek által érintett lakosok tervezett száma 14620 fö, a projekt közvetlenül járul hozzá 187 új munkahely létrehozásához.

A fö projektelemek és az azok által elérendő hatások tehát az alacsony energiafelhasználású városi negyedek létrehozása (megújuló energiaforrásokra támaszkodó fütési és hűtési rendszerekkel, osztott energiaelőállítással, energiahatékonyságot mérő és ellenőrző eszközökkel, elektromosáram-elosztási és fejlett épületenergetikai menedzsmenteszközökkel és -megoldásokkal); a fenntartható mobilitás (tiszta energiával működő járművek, megújított szállítási infrastruktúrák, energiafelhasználás- és szén-dioxid-csökkentési tervek); és integrált infrastruktúrák („smart grid” vagy okos hálózatalapú kapcsolatok, városi információs platformok, optimatizált közlekedési áramlások, multimodális közlekedési megoldások, valamint együttmüködésen és megosztáson alapuló információáramlás).

Tanulmányunk fó céljával és az azt megalapozó koncepcióval összhangban kiemeljük a REMOURBAN projekt nem technikai jellegü akcióit. A projektnek hangsúlyozott célja a nem műszaki jellegű akadályok és gátló tényezők beazonosítása, és olyan beavatkozások meghatározása, amelyek segítségével a városi fenntarthatóság, az optimális szabályozási háttér és az innovatív közbeszerzési eljárások kialakíthatók.

Ennek érdekében a projektben részt vevő partnerek nyolc intézkedést határoztak meg:

- közösségi részvételt és elköteleződést segítő eszközök: olyan jó gyakorlatok, módszerek összegyűjtése, kidolgozása, amelyek a közösségek és a lakosság motivációinak jobb megértését segítik;

- közösségi hálózati szabályozás: annak értékelése, hogy a közigazgatás hogyan tudná az egyéni közösségi hálózatosodási eszközöket a lehető 
leghatékonyabban kihasználni és célzottan irányítani a közösségi érdekek és a jólét maximalizálására;

- érdekeltségi platform: olyan fizikai és digitális felület létrehozása, amely az érdekelt szereplőket foglalja magában: vállalatokat, városokat, helyi önkormányzatokat és egyéneket. Az új vállalkozások, szervezetek és a lakosok számára mentorálás, konzultáció szervezése szakpolitikákról, fejlesztési tervekről.

- városi láthatóság: olyan vizualizációs technikák bevezetése és alkalmazása, amelyek a lakosok bekapcsolódását segítik a várostervezésbe, és a sokszor láthatatlan kezdeményezéseket, koncepciókat láthatóvá és érzékelhetővé teszik;

- okosváros-stratégia és intézkedési terv: olyan, az érdekeltek által támogatott stratégiai vízió, hosszú távú szakpolitika és megfelelő szabályozási háttér kialakítása, amely a hatékony megvalósítási folyamat alapját képezi;

- innovatív finanszírozási modellek: a finanszírozási eszközök és kötelezettségvállalások összehangolása, intelligens rendszerbe foglalása;

- okos energiatérkép: olyan dinamikus energiatérképek megalkotása, amelyek a közvetlen és közvetett energiatermelést és -felhasználást a különböző szektorok között láthatóvá és mérhetővé teszik;

- EU okos városok indikátor-keretrendszere: egy EU-s szintü okosvárosindikátorrendszer közös fejlesztése és kísérleti alkalmazása a létező mérési eszközök alkalmazásával és továbbfejlesztésével, a széles körű alkalmazás lehetőségének megteremtésével.

A REMOURBAN projekt bemutatásának végén hivatkozunk Miskolc Megyei Jogú Város Önkormányzata és a Miskolc Holding Zrt. legújabb közös kezdeményezésére, amely a „Smart Miskolc - Itt a helyem” szlogennel indult, és amelynek keretében a miskolci középiskolák diákjai versenyezhetnek maximum 2 perces videó készítésével arról, hogy hogyan képzelik el Miskolcot mint okos várost 50 év múlva. A videók a Smart City Miskolc Facebook-oldalon voltak megtekinthetők és a videókra érkező kedvelések száma alapján döntöttek a szervezők a verseny nyerteseiről.

Összefoglalásként megállapítható, hogy a projekttevékenységek komplex módon fedik le az „okosság” számos területét, mind technológiai, mind nem technológiai fókuszú intézkedések megvalósításával. A projekt keretében kidolgozott fenntarthatósági és okossági értékelési rendszer keretében lehetővé válik a világítótorony-városok jelenlegi helyzetének felmérése és összehasonlítása, valamint a követő városok esetében a tervezett beavatkozások hatásainak elemzése. Ezáltal a későbbiekben a indikátorok elemzése és összehasonlítása alapján jó eséllyel beazonosíthatóvá válnak a területi kiegyenlítődést támogató hatások.

Kritikai észrevétel, hogy a lakosság fokozottabb bevonására volna szükség a tervezési folyamatokban, a döntéshozatalban és a megvalósítás lépéseiben; a helyi szereplőket jobban kellene bátorítani, hogy az informatikai felületet használják és visszajelzéseket adjanak az önkormányzati döntésekkel kapcsola- 
tosan. Hatékonyabban lehetne fejleszteni a helyi lakosok digitális írástudását, valamint javítani kellene hozzáférésüket és lehetőségeiket az oktatási és képzési formákhoz. A tipikus európai uniós projektelemek átvételén és adaptálásán túlmenően az alulról jövő, elsősorban lakossági kezdeményezések fogadására, azok helyi intézkedéssé formálására és mielőbbi bevezetésére, az ezeket támogató intézményi és finanszírozási keretek megteremtésére nagyobb hangsúlyt lehetne fektetni. Egy települést nem fizikai infrastruktúrájának működése, sokkal inkább a helyi közösség tudatossága, saját jövőjének formálására való képessége tesz okossá. Az „okos életvitel” kapcsán a projekt erőteljesebben fókuszálhatna a kulturális intézmények és programok kapacitásának növelésére, az egészségügyi feltételek javítására és az egyéni biztonságra, valamint az oktatási intézményekre és a kulturális tevékenységek támogatására (Etli, Aksoylu 2016). A területi egyenlőtlenségek - kiemelten a város és vidéke viszonya - tekintetében erőteljesebb együttműködésre lenne szükség Miskolc és agglomerációja között, aminek egyik lépése a környező települések bevonása lehet a projektmegvalósításba, akár az eddigi tapasztalatok megosztása céljából. Mivel Magyarországon Miskolc úttörő városként valósítja meg a projektet, a 2021-2027 közötti európai uniós programozási időszakra történő felkészülést hazánk számára elősegíthetné a tapasztalatok, kihívások, jó és rossz gyakorlatok minél szélesebb körben történő megosztása. ${ }^{2}$

\section{Az Okos közösségek nemzetközi projekt}

A másik vizsgált nemzetközi projekt határ menti kistelepülések, egy mikrotérség okossá alakításáról szól. A megvalósítási helyszín „,a periféria perifériája”ként is meghatározható. A magyar-szlovák határ az Európai Unió egyik leghosszabb szárazföldi belső határa, összesen $679 \mathrm{~km}$. A projekt célterületén (1. ábra) 2016-ban a lakosságszám Nógrád megyében 193946 fő, a kassai járásban 796650 fó, a besztercebányai járásban 653024 fó volt az Eurostat adatai szerint. Nógrád megye területe $2544 \mathrm{~km}^{2}$ (hazánk egyik legkisebb megyéje), a besztercebányai járás területe $9454 \mathrm{~km}^{2}$ (a legnagyobb a szlovákiai regionális önkormányzatok között) és a kassai járás területe $6754 \mathrm{~km}^{2}$. A célterület teljes területe $18752 \mathrm{~km}^{2}$.

A Smart communities, azaz Okos közösségek nevü Interreg-projekt (smartcommunities.eu 2018) célterületeként kijelölt megyei (NUTS3) szintű területegységekben szinte minden társadalmi-gazdasági indikátor értéke folyamatosan romlott az elmúlt évtizedekben a hagyományos fejlesztéspolitikai beavatkozások ellenére. Bár a határtérség gazdasági és társadalmi szempontból meglehetösen heterogén, a projekt célterülete sok szempontból homogén gazdasági, társadalmi, kulturális, történelmi és környezeti adottságokkal rendelkezik. Ezért fejlesztése a leghatékonyabban határon átnyúló stratégiával és közös beavatkozásokkal valósítható meg. ${ }^{3} \mathrm{~A}$ határ menti terület másik sajátossága a 
1. ábra: az Okos közösségek projekt célterülete Target area of the Smart communities project

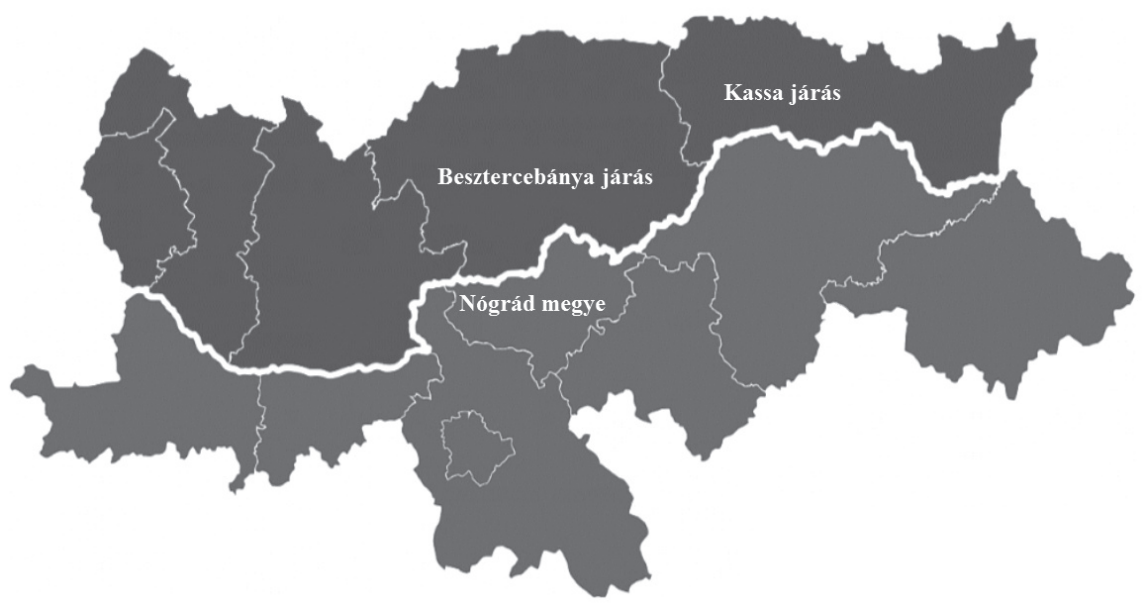

Forrás: Interreg V-A Slovakia-Hungary Cooperation Programme (2017) alapján saját szerkesztés.

jelentős magyar etnikum a határ szlovákiai oldalán, valamint a lakosság és a gazdasági szereplők fokozott integrációja. Több mint 30000 Szlovákiában élő lakos dolgozott például Magyarországon 2016-ban, így a határon túli ingázás napi gyakorlat (igaz, napjainkban a munkabérek gyors ütemü emelkedése és a régión belüli országverseny élesedése miatt ez a tendencia változni látszik). A bevásárlóturizmus virágzik, és a közös történelmi gyökereknek köszönhetően a határon átnyúló családi és baráti kapcsolatok száma is jelentős (Hardi 2008).

A projekt olyan modellt hozott létre és tesztelt, amely ötvözi a helyi sajátosságokat és a globális tendenciákat. A projekt 2017. május 1-jén indult, megvalósításának időtartama 2 év. A projektkonzorcium 8 szervezetből áll, négy-négy intézmény szerepel benne a határ mindkét oldaláról.

A projekt a terület fejlesztésének kulcsát nem elsősorban ipartelepítésben és a külföldi működő tőke vonzásában látja, sokkal inkább a szellemi kapacitások és az intellektuális tőke vonzásában és fejlesztésében, az eddigi, projektszintủ és ad hoc együttmüködések intézményesítésében és egy virtuális együttmüködési hálózat kialakításában, amelynek szereplői a helyi lakosok.

A két szektorális fókusz az információs-kommunikációs technológia és a fenntartható életmód. A fizikai infrastruktúrába történő befektetések helyett a projekt résztvevői a helyi lakosság digitális műveltségét fejlesztik. Ezáltal a lakosság számára lehetővé válik a legújabb trendekhez való közvetlen kapcsolódás: a rugalmas foglalkoztatásba és távmunkarendszerekbe (például müszaki távdiagnosztika, programozás) való bekapcsolódás, a fenntartható vidéki gazdálkodás módszereinek megismerése, az aktuális programokhoz (ipar 4.0, digitalizáció, a dolgok internete) való csatlakozás. A legkisebb falvakban a széles sávú internethez való kapcsolódáshoz a fizikai elérhetőségen túl szük- 
séges az erre való felkészülés, a digitális kompetenciák, a jártasság és a nyelvtudás megszerzése.

A projekt célterületén élők között magas a szociálisan marginalizálódott, többségében roma származású lakosok aránya, ezért ők alkotják a projekt célcsoportját, közöttük is az 5-18 éves korosztály. A pilot projekt célja a modell és a koncepció gyakorlati alkalmazásának tesztelése, amelynek alapján a kísérleti program kiterjeszthetővé válik más határ menti területekre vagy akár az egész országra. A célterületen belül a határ mindkét oldaláról 4-5 kistelepülésen történnek beavatkozások.

A projekttevékenységek egymásra épülnek, a két fő pillér a „soft” elemek fejlesztése, azaz a lakosság tudatosságának és részvételének növelése, valamint az intézményesítés. Az intézményesítés külön pillérként való szerepeltetése azért fontos, mert ez által biztosítható a létrejövő eredmények, a kialakult intézményközi együttműködések továbbélése, rendszerszintűvé válása és fenntarthatósága. Mindkét pilléren belül 6 tevékenység valósul meg, amelyeket a 2. ábra foglal össze.

A projekt kiinduló hipotézise az volt, hogy a célterületen élő - többségében hátrányos helyzetü - fiatalok motiválhatók, bekapcsolásuk, részvételük lehetséges a projekt tevékenységeibe. Az akciók az óvodáskortól indultak, motivációs bábjátékok szervezésével. Ezt követte az általános iskola felső évfolyamán tanuló diákok számára az iskolai IKT-klubok szervezése, ahol a gyerekek a programozás (C programnyelv) alapjait tanulják meg a digitális mágia tananyaga alapján. Ehhez első tevékenységként szükséges volt a határ mindkét oldalán általános iskolai tanárok képzése.

Annak elkerülése érdekében, hogy a gyerekek a tanultakat elfelejtsék, illetve motivációjukat elveszítsék, a nyári szünetben a projektpartnerek táboro-

2. ábra: Okos vidéki közösségek fejlesztésének koncepcionális modellje

Conceptual model of smart rural communities fevelopment

\begin{tabular}{|c|c|c|}
\hline \multirow{2}{*}{ SZEKTOR } & \multicolumn{2}{|c|}{ INFORMÁCIÓ-KOMMUNIKÁCIÓS TECHNOLÓGIA } \\
\hline & \multicolumn{2}{|c|}{ FENNTARTHATÓ ÉLETMÓD } \\
\hline FÓKUSZ & Lakossági részvétel & Intézményesítés \\
\hline \multirow{6}{*}{ AKCIÓ } & Képzők képzése & Virtuális OKFI Hálózat \\
\hline & Iskolai szakkörök & Smart IKT kompetenciaközpont \\
\hline & Nyári táborok & Fenntartható Élő Labor \\
\hline & Térségi Virág mentormozgalom & Okos Közösségek Akadémia \\
\hline & Motivációs és karriernapok & Szolgáltatásfejlesztés \\
\hline & Életpályamodellek & Smart Pilot Projektek \\
\hline
\end{tabular}


kat szerveztek a helyi gyerekek számára az IKT és a fenntartható életmód témaköreiben. A projektben részt vevő két felsőoktatási intézmény (a Szent István Egyetem és a Kassai Műszaki Egyetem) hallgatói és kollégái mentorprogramot valósítottak meg Térségi virág mozgalom címen, aminek keretében egy-egy mentor 6-8 gyermekkel foglalkozott egy éven keresztül. Közös és egyéni foglalkozásokat szerveztek, a projekt végén a zárókonferencián a gyermekek prezentációja arról fog szólni, hogy hogyan látják településüket 20-30 év múlva okos településként. Mivel fontos a szülők, nagyszülők, rokonok bevonása, így a motivációs és karriernapokat megszervezik a felnőtt célközönség számára is.

A projekttevékenységek infrastrukturális és szervezeti hátterét az intézményesítés pillére biztosítja, amelynek keretében a határ mindkét oldalán egyegy IKT-labor (Füleken és Salgótarjánban, valamint egy közös kompetenciaközpont) és a magyar oldalon egy fenntarthatóéletmód-oktatókert (Somoskőúffalun) valósul meg több tevékenységgel (például a középiskolások részére szervezett informatikai vetélkedővel és a lakosság körében attitűdfelméréssel, amelyet az MTA Közgazdaság- és Regionális Tudományi Kutatóközpontja végez). A projekt keretében két nemzetközi tudományos tanácskozást is rendeztek (Okos Közösségek Akadémia) (Áldorfai et al. 2017) Legénden és Ránkfüreden (Herlany). A projekt tevékenységeinek és eredményeinek fenntarthatóságát és terjeszthetöségét a létrehozott tananyagok, szolgáltatások, módszertanok és a projektmegvalósítás második felében kidolgozandó okos mintaprojektek fogják biztosítani. Mivel a projektnek nem az infrastrukturális fejlesztés és a közszolgáltatások fokozottabb digitalizációja a célja, a konzorciumi partnerek sem technológiai szolgáltatók és közműcégek, hanem felsőoktatási intézmények, akadémiai kutatóintézet, gimnázium és civil szervezetek. A projektkonzorcium vezetője a salgótarjáni székhelyü Interindustria Tudásközpont Alapítvány (ITA).

Az Okos közösségek projekt megvalósulásának várt eredményei:

- a célterületen élők szorosabb kapcsolódása a társadalmi-gazdasági-kulturális környezethez, a hazai és nemzetközi tendenciákhoz;

- tudatos életmód kialakítása, alternatív lehetőségek megismerése és életpályamodellek kialakítása;

- nyitottság az új technológiák és globális trendek felé, a digitális írástudás fejlesztése (kiemelten ipar 4.0, távmunka, „digitális nomád” életmód terjedése);

- nagyobb települési központokban a hozzáadott érték és az intellektuális erőforrások kritikus tömegének elérése;

- a projekt célterületének jobb láthatósága a gazdasági, társadalmi és természeti környezet széles körü bemutatásával;

- erősebb vonzerő mindenfajta befektetés (pénzügyi, humán, intellektuális) számára.

A projekt sikerét a hatásindikátorok javuló mutatói fogják remélhetően igazolni: középtávon növekedni fognak a hátrányos helyzetű célcsoport foglalkozta- 
tási esélyei, jobbak lesznek a foglalkoztatottsági mutatók, a távfoglalkoztatás lehetőségei bővülnek, ezáltal e térség területi elmaradottsága csökkenni fog.

A projekt egyik kiinduló állítása, hogy az okos települési programok hosszú távon a vidéki térségekben is fenntarthatók emberközpontú, helyi közösségeket fejlesztő megoldásokkal. Természetesen ez együtt jár a fizikai infrastruktúra „kritikus tömegének” létrehozásával, de e projekt hangsúlya a határ menti térség közösségeinek kulturális, oktatási együttmúködésén, intézményesítésén, hálózatok létrehozásán van. A projektmegvalósítás számos pozitív eredménye mellett szükséges megemlítenünk a kihívásokat is, mint például a helyi közösségekben az együttmüködők megtalálását és érdekeltté tételét, ezt követően a felelősségi és kompetenciakörök meghatározását, a kezdeti bizalmatlanság leküzdését, főként a szülők, nagyszülők meggyőzését a gyermekek számára és a velük együttműködésben végzett tevékenységek (például iskolai szakkör, nyári tábor, mentorálás, motivációs és karriernapok) hasznosságáról. Eddig kevésbé sikeres a helyi vállalkozói szféra bevonása: míg a közelben működő nagyvállalatokkal több területen alakult ki együttműködés, addig a helyi egyéni vállalkozók, kis- és közepes vállalkozások kevesebb érdeklődést és együttműködési hajlandóságot mutattak. Az is látható, hogy a projekt továbbvitele, fenntarthatóságának biztosítása kritikus fontosságú, hiszen míg az infrastruktúra-fejlesztések során a fejlesztés eredménye rögtön használatba vehető, addig a helyi közösségeket, lakosokat (főként gyermekeket) fejlesztő projektek esetében szükséges a folyamatos jelenlét, a lépcsőzetes építkezés, a kialakított közösség és érdeklődés, attitűd fenntartása. Ezért az ilyen típusú projektek megvalósításának időtartamát minimum háromnégy évben szükséges meghatározni.

\section{Összegzés, megállapítások}

A hazai városok „smart city”-vé alakulásának támogatása a kormányzat kiemelt célja, és számos város a zászlójára is tűzte ezek megvalósítását. Mindemellett a kezdeti lendületes lépéseket és az „alacsonyan függő gyümölcsök leszüretelését" követően napjainkban a fejlesztésekben átmeneti megtorpanás és iránykeresés mutatkozik. A települések közötti ,jó gyakorlatok" cseréje megindult, néhány szakmai konferencia is megvalósult ebben a témában az elmúlt években, ám az országos szintű koordináció csekély mértékű. A kormányzati szakmai és módszertani háttértámogatást elsősorban a Lechner Tudásközpont biztosítja magas színvonalon, a rendeleti szabályozást is kialakították, ám az országos szintű, rendszerszerű stratégiai programozási és forrásallokációs háttér nem áll rendelkezésre. A továbblépést számos tényező, például a megfelelő technikai-technológiai tudással és felkészültséggel rendelkező szakemberek hiánya vagy alacsony száma gátolja, elsősorban a kisebb településeken. 
Elsősorban a nagyvárosok, megyeszékhelyek aktívak az okos kezdeményezések megvalósításában. Az okos programok bevezetése azonban nem városi kiváltság, még akkor sem, ha a vidéki kistelepülések eddig kimaradtak az ilyen jellegü fejlesztésekből. A vidéki kistelepülések is okossá válhatnak lakosságszemléletű fejlesztésekkel, amelyek a fizikai infrastruktúra helyett a helyi közösségekre, az emberi tényezőre helyezik a hangsúlyt.

Két esettanulmányt mutattunk be, ahol európai uniós támogatással okos településfejlesztési programokat indítottak el 2015-ben, illetve 2017-ben. Az egyik - jobbára technológiai fókuszú - programot Miskolcon, míg a másik programot a szlovák-magyar határ menti térség falvaiban valósítják meg. Ez utóbbi joggal tekinthető kísérleti mintaprogramnak, mivel elsősorban nem a fizikai infrastruktúra kiépítése a célja, hanem a határ két oldalán élő lakosság tudásának fejlesztése, a modern ismeretek terjesztése, a szellemi erőforrások együttes használata közös programok, intézmények létrehozásával. A projektek még nem értek véget, csak részidős tapasztalatokkal rendelkezünk.

A kutatás eredményei alapján mindkét nemzetközi projekt eddigi megvalósulásának tapasztalatai azt támasztják alá, hogy az okos kezdeményezések erős potenciállal rendelkeznek mind a PPP-típusú együttmüködések generálása és ezáltal a fejlesztésekhez szükséges kritikus tömegü erőforrások megszerzése terén, mind pedig a lakosság bekapcsolásának, fokozott részvételének, tudatosságának elérésében. Kritikai észrevételként a helyi lakosság bevonása és érdekeltté tétele, az alulról jövő kezdeményezések befogadása, a települési közigazgatási határ elválasztó szerepe, a gyüjtött adatok etikus és átlátható felhasználása, a gazdasági szférával való konkrét együttműködési területek beazonosítása, valamint az eredmények, tapasztalatok társadalmasítása, kiértékelése kapcsán fogalmazhatók meg. Ez utóbbi azért is fontos, mert a nemzetközi gyakorlat alapján ezek a kezdeményezések nem mindig sikertörténetek: Amszterdam, a világ egyik vezető okos városa saját virtuális innovációs temetővel is rendelkezik, ahol a sikertelen kezdeményezéseket tartják nyilván. Mindezek ellenére a legfontosabb üzenet, hogy el kell kezdeni valahol, nem tervezgetni kell, hanem cselekedni.

\section{Köszönetnyilvánítás}

A szerzők köszönetet mondanak id. Paróczai Péter tanár úrnak az elmaradott térségek fejlesztése kapcsán végzett áldozatos, több évtizedes munkájáért, valamint szakmai és emberi támogatásáert az Okos közösségek projekt előkészítésében és megvalósításában. Külön köszönet illeti az anonim lektorokat és az olvasószerkesztőt értékes észrevételeikért, javaslataikért. 


\section{Jegyzetek}

1 A városi labor egy valós kísérleti és tesztelőközeg, ahol a felhasználók és a fejlesztők közösen dolgoznak egy-egy szolgáltatás, termék vagy alkalmazás fejlesztésén. A városi laborok az Európai Bizottság definíciója szerint olyan PPP-konstrukciók, melyek célja a felhasználóorientált, nyílt innováció támogatása (Lechner Központ 2018).

2 Kiemelten fontos mindez a hazai települések (elsősorban nagyvárosok) innovációs rendszerben betöltött szerepe és a következő, Horizont Európa névre keresztelt európai uniós kutatásfejlesztési és innovációs keretprogram kapcsán.

3 Határon átnyúló stratégiai együttműködésre jó példa a NORRIS projekt, amelynek keretében az Európai Unió 5. keretprogramjának társfinanszírozásával a határ menti terület közös regionális innovációs stratégiáját dolgozta ki egy nemzetközi konzorcium. A projekt európai uniós szinten példaértékű, és a módszertan határon átnyúló alkalmazhatóságára is alkalmasnak bizonyult. A későbbiekben több hasonló projektet valósítottak meg sikeresen az érintett partnerek.

\section{Irodalom}

Áldorfai, Gy., Józsa, V., Káposzta, J., Nagy, H., Varga-Nagy, A. (2017): Challenges and development paths of Central and Eastern European locations in the globalised world - Report on the first International Smart Communities Academy. Deturope, 3., 229-232.

Allwinkle, S., Cruickshank, P. (2011): Creating smarter cities: An overview. Journal of Urban Technology, 2., 1-16. http://doi.org/d8vk9f

Bakici, T., Almirall, E., Wareham, J. (2013): A smart city initiative: The case of Barcelona. Journal of the Knowledge Economy, 2., 135-148. http://doi.org/fzjb45

Boltanski, L., Thévenot, L. (2006): On justification: Economies of worth. Princeton University Press, Princeton

Callon, M. (1986): Éléments pour une sociologie de la traduction: La domestication des coquilles saint-jacques et des marins-pecheurs dans la baie de saint-brieuc. L'Année sociologique, 36., 169-208.

Caragliu, A., Del Bo, C., Nijkamp, P. (2011): Smart cities in Europe. Journal of Urban Technology, 2., 65-82. http://doi.org/cn9pvp

Etli, P., Aksoylu, S. (2016): Critical outlook to Remourban Project of Eskişehir Tepebaş1 - Municipality as a smart settlement. Proceedings of the 5th International Conference on Smart Cities and Green ICT Systems. Rome, Italy, April 23-25. 86-93. http://doi.org/c2m4

Hardi, T. (ed.) (2008): Transborder movements and relations in the Slovakian-Hungarian border regions. Centre for Regional Studies, Pécs (Discussion Papers; 68.)

Hollands, R. G. (2008): Will the real smart city please stand up? City, 3., 303-320. http://doi.org/dwm6g5

http://www.remourban.eu (Letöltés: 2018. március 31.)

http://www.smartcommunities.eu (Letöltés: 2018. április 3.)

Interreg V-A Slovakia-Hungary Cooperation Programme (2017) http://www.skhu.eu/programme (Letöltés: 2018. február 11.)

Lechner Központ (2018): Okos Város Példatár. http://www.okosvaros.lechnerkozpont.hu (Letöltés: 2018. március 31.)

Morandi, C., Rolando, A., Di Vita S. (2016): From smart city to smart region. Digital services for an internet of places. Springer, Milan http://doi.org/c2m5

Naldi, L., Nilsson, P., Westlund, H. (2015): What is smart rural development? Journal of Rural Studies, 40., 90-101. http://doi.org/f3nb4z

Paskaleva, K. A. (2011): The smart city: A nexus for open innovation? Intelligent Buildings International, 3., 153-171. http://doi.org/d9xfwg 
Rat-Fischer, C., Rapp, F., Meidl, P., Lewald, N. (2012): Smart city: Energy efficiency in a new scope. Resilient Cities, 2., 119-124. http://doi.org/c2m6

Söderström, O., Paasche, T., Klauser, F. (2014): Smart cities as corporate storytelling. City, 3., 307-320. http://doi.org/gd57fs

Vanolo, A. (2014): Smartmentality: The smart city as disciplinary strategy. Urban Studies, 5., 883-898. http://doi.org/f5xvjg

Vermast, F-A. (2018): Smart cities in CEE. Conference presentation, 2018. április 19. https://www. smartcitiescee.com/ (Letöltés: 2018. április 25.) 